I-Finance Vol. 3. No. 2. Desember 2017

Pengaruh Price Earning Ratio ....Lidia Desiana

\title{
PENGARUH PRICE EARNING RATIO (PER), EARNING PER SHARE (EPS), DEVIDEND YIELD RATIO (DYR), DIVIDEND PAYOUT RATIO (DPR), BOOK VALUE PER SHARE (BVS) DAN PRICE BOOK VALUE(PBV) TERHADAP HARGA SAHAM PADA PERUSAHAAN SUBSEKTOR MAKANAN DAN MINUMAN YANG TERDAFTAR DI JAKARTA ISLAMIC INDEX (JII)
}

\author{
Lidia Desiana ${ }^{1}$ (desiana_lidia@yahoo.co.id)
}

\begin{abstract}
One of the financial ratios that can be used to provide information on how much society (investors) or shareholders appreciates the company, so they want to buy stockof the company at a higher price than the book value of stock is the ratio of share capital or market ratio. This research aims to prove the influence of PriceEarning Ratio (PER), Earning Per Share (EPS), Devidend Yield Ratio (DYR), Dividend Payout Ratio (DPR), Book Value per Share (BVS) and Price Book Value $(P B V)$ Sharia shares. The sample in this research consists of two sub-sector food and beverage companies listed in Jakarta Islamic Index, namely PT. Indofood CBP Sukses Makmur, Tbk and PT. Indofood Sukses Makmur, Tbk. To explain the influence of these variables, the data obtained in this research were analyzed using multiple linear regression model. The result of T test shows that Price Earning Ratio (PER), EarningPer Share (EPS), Book Value Per Share (BVS) and Price Book Value $(P B V)$ have an effect on stock price. Devidend Yield Ratio (DYR) and Devidend Payout Ratio (Parliament) partially have no effect on stock prices. F test results show that Price Earning Ratio (PER), Earning Per Share (EPS), Devidend Yield Ratio (DYR), Devidend Payout Ratio (DPR), Book Value Per Share (BVS), Price Book Value $(P B V)$ simultanly have effect on stock prices.
\end{abstract}

Keywords: Price Earning Ratio, Earning Per Share (EPS), Devidend Yield Ratio (DYR), Devidend Payout Ratio (DPR), Book Value Per Share (BVS), Price Book Value (PBV) and Sharia Stock Price

\section{PENDAHULUAN}

Pada 20 Mei 2013, laju IHSG sempat mengalami rekor penurunan terbesar yaitu hingga $20,81 \%$ yang terjadi akibat adanya dua sentimen negatif, pertama ketakutan yang besar atas rencana bank sentral AS, The Federal Reserve untuk mengurangi kucuran dalam programnya quantitative easing $(\mathrm{QE})$, dan kedua adalah makroekonomi dalam negeri yang tampak kurang solid. Akibatnya, para investor asing pun merasa hati-hati untuk berinvestasi dan sedikit demi sedikit keluar dari bursa sahamdomestik. ${ }^{2}$

\footnotetext{
${ }^{1}$ Dosen Fakultas Ekonomi UIN Raden Fatah Palembang

2 Analisis Forex, "Prospek Investasi Saham", Http://analisaforex.com.10/02/2014/prospekinvestasi-saham-2014/4983.html. ( diakses, 20 November 2015)
} 
I-Finance Vol. 3. No. 2. Desember 2017

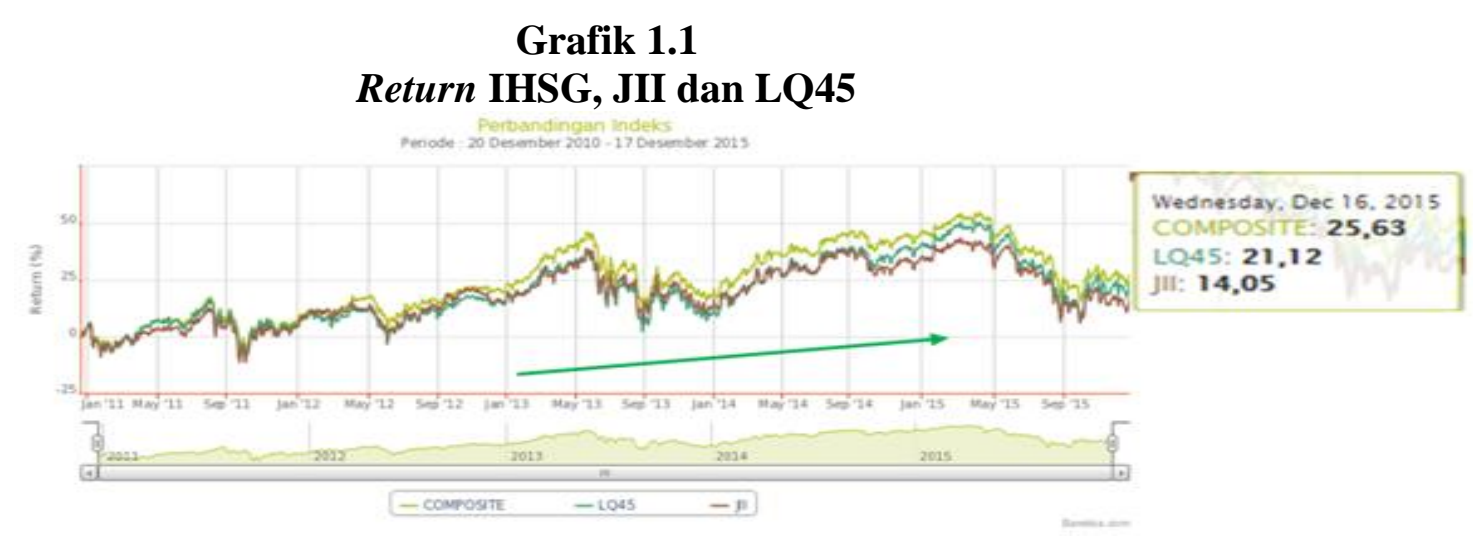

Sumber: www.bareksa.com

Berkurangnya jumlah pemain dari bursa saham domestik ini terlihat pada catatan transaksi investor asing yang merekam penjualan bersih (net sell) sepanjang year to date (YTD) per 22 november 2013 yang mencapai Rp 24,9 triliun atau rekor terdalam selama 8 tahun terakhir. Arus dana keluar investor asing yang terjadi selama 4 bulan berturut-turut mulai dari bulan Mei hingga Agustus 2013 sebesar Rp 39,8 triliun menyebabkan naiknya nilai mata uang dollar Amerika terhadap rupiah hingga mencapai Rp 11.000 per dollar Amerika. ${ }^{3}$

Permasalahan tersebut tidak terlalu berdampak terhadap investasi saham syariah. Seperti halnya JII, ISSI ditutup pada 170,80 poin atau meningkat sebesar $18,85 \%$ dibandingkan indeks ISSI pada akhir tahun 2013 sebesar 143,71 poin. Sementara itu, kapitalisasi pasar saham yang tergabung dalam ISSI per 13 Agustus 2014 sebesar Rp 3.025,63 triliun atau 58,93\% dari total kapitalisasi pasar seluruh Saham (Rp 5.134,30 triliun). Kapitalisasi pasar saham ISSI pada 13 Agustus 2014 tersebut mengalami peningkatan sebesar 18,29\% jika dibandingkan kapitalisasi pasar saham ISSI pada akhir tahun 2013 sebesar Rp2.557,85 triliun. ${ }^{4}$

Perusahaan yang memiliki kinerja cukup baik akan lebih diminati oleh para investor, karena kinerja perusahaan mempengaruhi harga saham di pasar. investor akan membeli saham sesuai kinerja perusahaan saat ini dan prospeknya di masa yang akan datang. Oleh karena itu, kinerja perusahaan yang meningkat akan berpengaruh pada meningkatnya harga saham dan diharapkan returnsaham yang dapat diterima investor meningkat. Berikut data harga saham perusahaan sub sektor food and beverage yang terdaftar di Jakarta Islamic Indeks (JII) tahun 2011-2015:

3 Analisis Forex, "Prospek Investasi Saham”, Http://analisaforex.com.10/02/2014/prospekinvestasi-saham-2014/4983.html. ( diakses, 20 November 2015) 
I-Finance Vol. 3. No. 2. Desember 2017

Pengaruh Price Earning Ratio ....Lidia Desiana

Grafik 1.1

Perkembangan Harga Saham Sub Sektor Food and Beverage yang Terdaftar di Jakarta Islamic Indeks (JII) Tahun 2011-2015

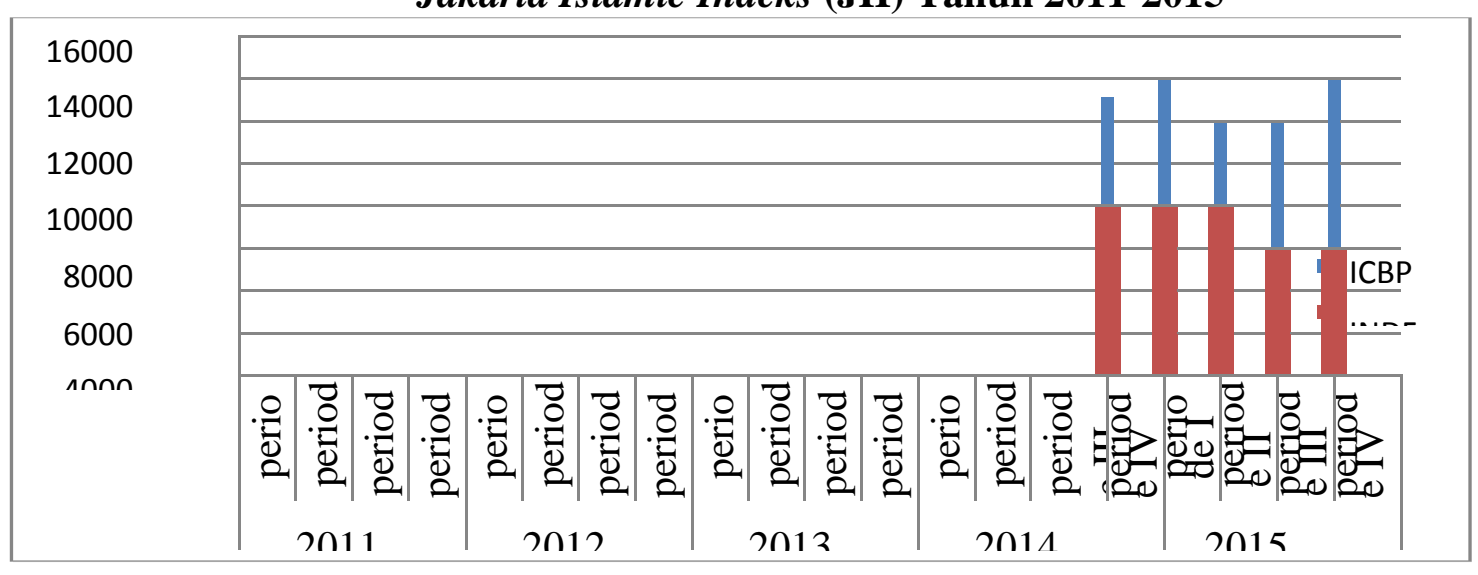

Dapat disimpulkan bahwa harga saham ICBP dan INDF terjadi perubahan tiap periodenya. Beberapa banyak faktor yang mempengaruhi harga saham dan returnsaham, baik yang bersifat makro maupun mikro ekonomi. Faktor makro ada yang bersifat ekonomi maupun nonekonomi.Faktor makroekonomi terinci dalam beberapa variabel ekonomi, misalnya inflasi, suku bunga, kurs, valuta asing, tingkat pertumbuhan ekonomi, harga bahan bakar minyak di pasar internasional, dan indeks saham regional.Faktor makro nonekonomi mencakup peristiwa politik domestik, peristiwa sosial, peristiwa hukum, dan peristiwa politik internasional. Sementara itu, faktor mikroekonomi misalnya laporankeuangan. ${ }^{13}$ Rasio keuangan dikelompokkan menjadi lima jenis berdasarkan ruang lingkup atau tujuan yang ingin dicapai, yaitu rasio likuiditas, rasio solvabilitas (leverage), rasio rentabilitas (profitabilitas), rasio aktivitas, dan rasio pasar (market ratios). ${ }^{4}$

Rasio pasar merupakan sekumpulan rasio yang menghubungkan harga saham dengan laba dan nilai buku per saham. Rasio ini memberikan petunjuk mengenai apa yang dipikirkan invenstor atas kinerja perusahaan di masa lalu serta prospek di masa mendatang. ${ }^{15}$ Rasio ini memberikan informasi seberapa besar masyarakat (investor) atau para pemegang saham menghargai perusahaan, sehingga mereka mau membeli saham perusahaan dengan harga yang lebih tinggi di banding dengan nilai buku saham. ${ }^{5}$

\section{METODOLOGI PENELITIAN}

\section{A. Jenis dan Sumber Data}

Jenis data yang digunakan dalam penelitian ini adalah data sekunder yang berupa laporan keuangan dan harga saham dari perusahaan food and beverage yang terdaftar di Jakarta Islamic indeks (JII) tahun 2011-2015. Sumber data yaitu berupa laporan keuangan perusahaan sub sektor food and beverage yang terdaftar di Jakarta Islamic Indeks (JII) diperoleh dari situs www.idx.co.id dan data harga saham di peroleh dari situs www.yahoofinance.com yang diambil per triwulan

${ }^{4}$ Robert Ang, Buku Pintar Pasar Modal Indonesia, hlm. 18-23

${ }^{5}$ Sutrisno, Manajemen Keuangan. (Yogyakarta: Cetakan Ketiga, Ekonosia, 2003), hlm.256 
I-Finance Vol. 3. No. 2. Desember 2017

Pengaruh Price Earning Ratio ....Lidia Desiana

dari tahun 2011-2015. Penelitian ini menggunakan data panel (gabungan antara dua data times series dan data cross section).

\section{B. Populasi dan Sampel}

Populasi pada penlitian ini adalah perusahaan yang menjadi emiten di Jakarta Islamic Indeks (JII) tahun 2011 -2015.Teknik pengambilan sampel yang digunakan dalam penelitian ini adalah purposive sampling.Peneliti ini menggunakan purposive sampling dalam memilih perusahaan sub sektor food and bevarage dengan kriteria sebagai berikut :

a. Perusahaan sub sektor food and beverage menyediakan laporan keuangan secara lengkap selama periode2011-2015.

b. Laporan keuangan yang disediakan merupakan laporan keuangan triwulan pada periode 2011-2015 yang telah dipublikasikan oleh Bursa Efek Indonesia (BEI).

c. Perusahaan sub sektor food and beverage memiliki data yang dibutuhkan terkait pengukuran variabel-variabel yang digunakan untuk penelitian selama periode2011-2015.

Tabel 3.1

Daftar Perusahaan Sub Sektor Food and Beverage Yang Terdaftar di Jakarta Islamic Indeks (JII) tahun 2011 - 2015.

\begin{tabular}{|l|l|l|}
\hline No & Kode Saham & \multicolumn{1}{|c|}{ Nama Perusahaan } \\
\hline 1 & ICBP & PT Indofood CBP Sukses Makmur Tbk, \\
\hline 2 & INDF & PT Indofood Sukses Makmur Tbk, \\
\hline
\end{tabular}

Tabel 3.2

Definisi Operasional Variabel

\begin{tabular}{|c|c|c|c|}
\hline No & Variabel & $\begin{array}{r}\text { Pengertian } \\
\end{array}$ & Cara Pengukuran \\
\hline 1 & Harga saham & $\begin{array}{l}\text { Rasio perbandingan antara modal } \\
\text { perusahaan dan jumlah saham yang } \\
\text { diterbitkan atau perbandingan antara } \\
\text { nilai intrinsik saham dengan harga }\end{array}$ & Last price \\
\hline 2 & $\begin{array}{l}\text { Price } \\
\text { EarningRatio } \\
\text { (DDD) }\end{array}$ & $\begin{array}{l}\text { Rasio perbandingan antara harga per } \\
\text { lembar saham dan laba per lembar }\end{array}$ & $\begin{array}{l}\text { Harga per lembar saham laba } \\
\text { per lembar saham }\end{array}$ \\
\hline 3 & $\begin{array}{l}\text { Earning Per } \\
\text { Share (EPS) }\end{array}$ & $\begin{array}{l}\text { Rasio perbandingan antara laba } \\
\text { bersih dan jumlah saham yang } \\
\text { beredar }\end{array}$ & $\frac{\text { Laba bersih }}{\text { Jumlah saham yang beredar }}$ \\
\hline 4 & $\begin{array}{l}\text { Devidend Yield } \\
\text { Ratio (DYR), }\end{array}$ & $\begin{array}{l}\text { Rasio perbandingan antara deviden } \\
\text { per lembar saham dan harga per } \\
\text { lombar }\end{array}$ & $\begin{array}{l}\text { Deviden per lembar } \\
\text { sahamx } 100 \%\end{array}$ \\
\hline 5 & $\begin{array}{l}\text { Devidend } \\
\text { Payout Ratio } \\
\text { nDD }\end{array}$ & $\begin{array}{l}\text { Rasio perbandingan antar deviden per } \\
\text { lembar saham dan laba per lembar }\end{array}$ & $\begin{array}{l}\text { Deviden per lembar } \\
\text { sahamx } 100 \%\end{array}$ \\
\hline 6 & $\begin{array}{l}\text { Book Value Per } \\
\text { Share (BVS), }\end{array}$ & $\begin{array}{l}\text { Rasio perbandingan antara jumlah } \\
\text { keseluruhan ekuitas perusahaan } \\
\text { dengan jumlah saham yang beredar }\end{array}$ & $\begin{array}{c}\text { Total ekuitas } \\
\text { perusahaanx } 100 \%\end{array}$ \\
\hline 7 & $\begin{array}{l}\text { Price Book } \\
\text { Value (PBV) }\end{array}$ & $\begin{array}{l}\text { Rasio perbandingan antara harga } \\
\text { pasar dan harga nilai buku }\end{array}$ & Harga pasar \\
\hline
\end{tabular}


I-Finance Vol. 3. No. 2. Desember 2017

Pengaruh Price Earning Ratio ....Lidia Desiana

\section{Sumber : dikumpulkan dari berbagai sumber \\ C. Teknik Analisis Data}

Penelitian ini menggunakan metode analisis regresi linier berganda.Analisis regresi linier berganda adalah suatu analisis asosiasi yang digunakan secara bersamaan untuk meneliti pengaruh dua atau lebih variabel bebas terhadap satu variabel tergantung dengan skala interval. ${ }^{6}$ Penggunaan metode ini untuk menganalisis pengaruh Price Earning Ratio (PER), Earning Per Share (EPS), Devidend Yield Ratio (DYR), Devidend Payout Ratio (DPR), Book Value Per Share (BVS), Price Book Value (PBV) terhadap harga saham dengan model dasar dapat ditulis sebagai berikut: persamaan matematika sebagai berikut :

$$
\mathrm{Y}=\mathrm{a}+\mathrm{b} 1 \mathrm{X} 1+\mathrm{b} 2 \mathrm{X} 2+\mathrm{b} 3 \mathrm{X} 3+\mathrm{b} 4 \mathrm{X} 4+\mathrm{b} 5 \mathrm{X} 5+\mathrm{b} 6 \mathrm{X} 6+\mathrm{e}
$$

Dimana :

$\mathrm{Y}=$ Harga saham perusahaan sub sektor food and beverage

$\mathrm{a}=$ Konstanta

b1b2b3b4b5b6 = Koefision X1, X2, X3, X4, X5, X6

$\mathrm{X} 1=$ Price Earning Ratio $(\mathrm{PER})$

$\mathrm{X} 2=$ Earning Per Share (EPS)

$\mathrm{X} 3=$ Devidend Yield Ratio (DYR)

$\mathrm{X} 4=$ Devidend Payout Ratio (DPR)

$\mathrm{X} 5$ = Book Value Per Share (BVS)

$\mathrm{X} 6=$ Price Book Value (PBV)

$\mathrm{e}=$ Tingkat Error, tingkat kesalahan

\section{HASIL DAN PEMBAHASAN}

\section{A. AnalisisData}

AnalisisDeskriptif

Tabel 4.1

Descriptive Statistics Variabel PER, EPS, DYR,DPR,BVS,PBV dan Harga Saham

\begin{tabular}{|c|c|c|c|c|c|}
\hline & $\mathrm{N}$ & Minimum & Maximum & Mean & Std. Deviation \\
\hline Harga saham & 40 & 8,43 & 9,59 & 8,8935 & 34031 \\
\hline PER & 40 & 2,57 & 3,72 & 2,9955 & ,28636 \\
\hline EPS & 40 & 4,30 & 7,00 & 5,4545 & 57612, \\
\hline DYR & 40 & ,41 & 1,45 & ,9324 & 28763, \\
\hline DPR & 40 & 3,64 & 5,43 & 4,4326 & 51657, \\
\hline BVS & 40 & 7,42 & 8,50 & 8,0200 & 34963, \\
\hline PBV & 40 & ,00 & 1,81 & 1,1220 & , 41200 \\
\hline Valid & 40 & & & & \\
\hline (listwis & & & & & \\
\hline
\end{tabular}

Dari Tabel 4.1 bahwa jumlah observasi perusahaan sub sektor food and beverages adalah sebanyak 40 data selama periode 2011-2015. Dari hasil perhitungan, dapat diketahui nilai terendah harga saham 8,43 dan nilai tertingginya

${ }^{6}$ Umi Narimawati, Metodologi Penelitian Kualitatif dan Kuantitatif, Teori dan Aplikasi, (Bandung: Agung Media, 2008), hlm. 5 
I-Finance Vol. 3. No. 2. Desember 2017 Pengaruh Price Earning Ratio ....Lidia Desiana

9,59 dengan rata-ratanya 8,8935, sedangkan standar deviasi 0,34031. PER adalah 2,57 dan nilai tertingginya 3,72 dengan rata-ratanya 2,9955, sedangkan standar deviasi 0,28636. EPS memiliki nilai terendah sebesar 4,30 dan nilai tertingginya 7,00 dengan rata-ratanya 5,4545, sedangkan standar deviasi 0,57612. DYR memiliki nilai terendah sebesar 0,41 dan nilai tertingginya 1,45 dengan rata-ratanya 0,9324 , sedangkan standar deviasi 0,28763. DPR memiliki nilai terendah sebesar 3,64 dan nilai tertingginya 5,43 dengan rata-ratanya 4,4326 sedangkan standar deviasi 0,51657 . BVS memiliki nilai terendah 7,42 dan nilai tertingginya 8,50 dengan rataratanya 8,0200 , sedangkan standar deviasi 0,34963 . PBV memiliki nilai terendah 0,00 dan nilai tertingginya 1,81 dengan rata-ratanya 1,1220 , sedangkan standar deviasi 0,41200 .

\section{Uji Normalitas}

\section{Gambar 4.1 Normal P-PLOT}

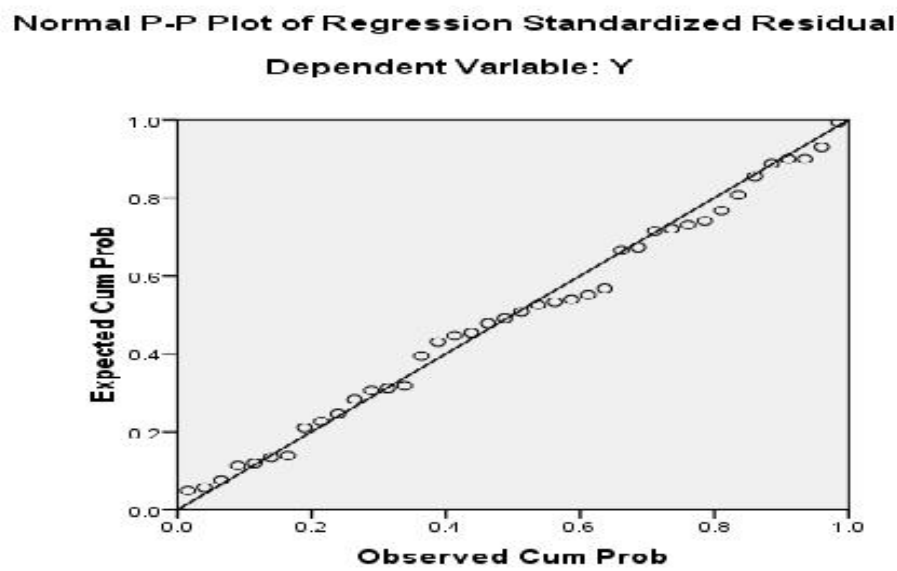

Dari Gambar 4.1 bahwa pola distribusi normal, data menyebar disekitar garis diagonal dan mengikuti arahnya.Maka dapat disimpulkan bahwa asumsi normalitas telah terpenuhi.

Selain dengan melihat grafik, asumsi normalitas juga dapat menggunakan uji statistik yaitu dengan uji Komlogorov-Smirnov. Dalam pengujian ini, data dikatakan terdistribusi secara normal apabila hasil dari (sig) $>0,05$.

Tabel 4.2

Hasil Uji Normalitas Kolmogorov-Smirnov One-Sample Kolmogorov-Smirnov Test

\begin{tabular}{|lc|c|}
\hline & & Residual \\
\hline $\mathrm{N}$ & & 40 \\
NormalParametersa & Mean &, 0000000 \\
& Std. Deviation & 10764928 \\
Most Extreme Differences Absolute &, 077 \\
& Positive &, 077 \\
& Negative &,- 049 \\
\multicolumn{1}{|c|}{ Kolmogorov-Smirnov Z } &, 485 \\
Asymp. Sig. (2-tailed) &, 973 \\
\hline
\end{tabular}

. a. Test distribution is Normal.

b. Calculated from data. 
I-Finance Vol. 3. No. 2. Desember 2017

Pengaruh Price Earning Ratio ....Lidia Desiana

Dari Tabel 4.2 bahwa semua variabel dalam penelitian ini dapat dikatakan normal karena nilai asymptotic significance adalah sebesar 0,973 lebih besar dari nilai signifikansi yang telah ditetapkan yaitu 0,05 .

\section{Uji Multikolinieritas}

Uji multikolinieritas digunakan untuk mengetahui apakah ada atau tidaknya hubungan linear antar variabel independen dalam model regresi.Uji multikolinieritas dilihat dari nilai Tolerance dan lawannya Variance Inflation Factor (VIF). Apabila nilai toleransi $>0,10$ dan VIF $<10$, maka tidak adamultikolinieritas.Hasil uji multikolinieritas dapat dilihat pada tabel di bawah ini:

Tabel 4.3

Hasil Uji Multikolinieritas

Coefficients $\mathbf{a}$

\begin{tabular}{|c|c|c|}
\hline \multirow{2}{*}{ Model } & Collinearity & Statistics \\
\hline & Tolerance & VIF \\
\hline (Constant) & & \\
\hline PER & 332 & 3,009 \\
\hline EPS & , 403 & 2,481 \\
\hline DYR & ,279 & 3,588 \\
\hline DPR & ,391 & 2,555 \\
\hline BVS & ,500 & 1,999 \\
\hline PBV & .231 & 4,336 \\
\hline
\end{tabular}

Berdasarkan Tabel 4.3 dapat diketahui nilai Tolerance dan VIF untuk masing-masing variabel penelitian sebagai berikut:

a. Nilai Tolerance untuk variabel PER sebesar 0,332 > 0,10 dan nilai VIF sebesar $3,009<10$, sehingga variabel PER dinyatakan tidak terjadi gejala multikolinieritas.

b. Nilai Tolerance untuk variabel EPS sebesar 0,403 > 0,10 dan nilai VIF sebesar $2,481<10$, sehingga variabel EPS dinyatakan tidak terjadi gejala multikolinieritas.

c. Nilai Tolerance untuk variabel DYR sebesar 0,279>0,10 dan nilai VIF sebesar $3,588<10$, sehingga variabel DYR dinyatakan tidak terjadi gejala multikolinieritas.

d. Nilai Tolerance untuk variabel DPR sebesar 0,391 > 0,10 dan nilai VIF sebesar $2,555<10$, sehingga variabel DPR dinyatakan tidak terjadi gejala multikolinieritas.

e. Nilai Tolerance untuk variabel BVS sebesar 0,500>0,10 dan nilai VIF sebesar $1,999<10$, sehingga variabel BVS dinyatakan tidak terjadi gejala multikolinieritas.

f. Nilai Tolerance untuk variabel PBV sebesar 0,231 > 0,10 dan nilai VIF sebesar $4,336<10$, sehingga variabel PBV dinyatakan tidak terjadi gejala multikolinieritas. 
I-Finance Vol. 3. No. 2. Desember 2017 Pengaruh Price Earning Ratio ....Lidia Desiana

\section{Uji Autokorelasi}

Uji Autokorelasi digunakan untuk mengetahui ada atau tidaknya penyimpangan asumsi klasik autokolerasi, yaitu kolerasi yang terjadi antara residual pada satu pengamatan dengan pengamatan lain pada model regresi. Persyaratan yang harus terpenuhi adalah tidak adanya autokorelasi dalam model regresi. Metode pengujian yang akan digunakan adalah dengan uji Durbin-Watson (Uji DW).

Tabel 4.4

Hasil Uji Autokorelasi

Model Summaryb

\begin{tabular}{|l|l|}
\hline Model & Durbin-Watson \\
\hline 1 & 1,507 \\
\hline
\end{tabular}

a. Predictors: (Constant), PER,EPS,DYR, DPR,BVS,PBV

b. Dependent Variable: hargasaham

Sumber: Output SPSS versi 20, 2015

Dari Tabel 4.4 bahwa nilai DW 1,507.Berdasarkan kriteria pengambilan keputusan bahwa nilai DW diantara -2 sampai +2 berarti tidak terjadi autokorelasi.

\section{Uji Heteroskedastisitas}

\section{Gambar 4.2}

Hasil Uji Heteroskedastisitas

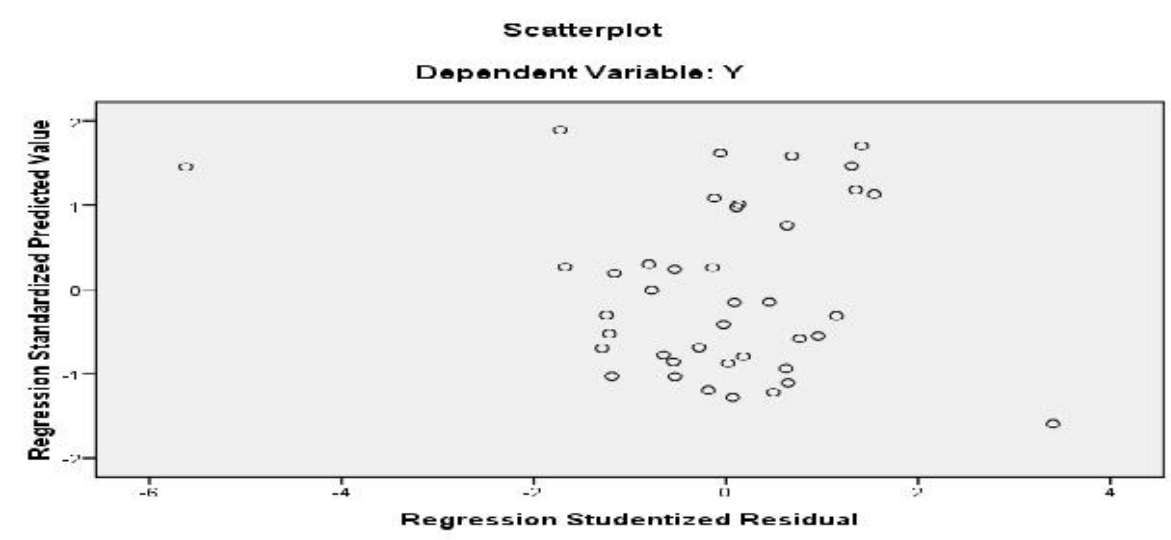

Sumber: Output SPSS versi 20, 2015

Dari Gambar 4.2 bahwa titik-titik menyebar secara acak dan merata diatas sumbu $\mathrm{X}$ ataupun $\mathrm{Y}$, tidak berkumpul disuatu tempat serta tidak membentuk pola tertentu, maka dapat disimpulkan bahwa tidak terjadi masalah heteroskedastisitas.

\section{B. Uji Hipotesis}

\section{Uji Koefisien Determinasi $\left(\mathbf{R}^{2}\right)$}

\section{Tabel 4.5}

Hasil Uji Koefisien Determinasi $\left(\mathbf{R}^{\mathbf{2}}\right)$

Model Summaryb

\begin{tabular}{|l|l|l|l|l|l|}
\hline Model & $R$ & R Square & Adjusted & R & Std. Error of the \\
\hline 1 & $.949 \mathrm{a}$ &, 900 &, 882 &, 11703 & \\
\hline
\end{tabular}

Predictors: (Constant), PER,EPS,DYR, DPR, BVS,PBV 
I-Finance Vol. 3. No. 2. Desember 2017

Pengaruh Price Earning Ratio ....Lidia Desiana

Dari Tabel 4.5 diketahui pengaruh dari keenam variabel independen (PER, EPS, DYR, DPR, BVS, PBV ) terhadap dependen (harga saham) dinyatakan dalam nilai $R^{2}$ yaitu sebesar 0,882 atau $88,2 \%$. Artinya $88,2 \%$ variabel harga saham bisa dijelaskan oleh keenam variabel independen dalam penelitian yaitu PER, EPS, DYR, DPR, BVS, PBV secara bersama- sama. Sedangkan 11,8 \% sisanya dijelaskan oleh rasio keuangan yang lain diluar model penelitian ini.

\section{Uji F(Simultan)}

Tabel 4.6 Uji F (Simultan)

ANOVAa

\begin{tabular}{|ll|ll|l|l|l|l|}
\hline Model & & Sum & of & Df & Mean Square & F & Sig. \\
\hline \multirow{4}{*}{1} & Regression & 4,065 & 6 &, 677 & 49,465 &, $000^{\mathrm{a}}$ \\
& Residual &, 452 & 33 &, 014 & & \\
& Total & 4,517 & 39 & & & \\
\hline
\end{tabular}

a. Dependent Variable: hargasaham

b. Predictors: (Constant), PER, EPS, DYR, DPR, BVS,PBV

c. Sumber: Output SPSS versi 20, 2015

Berdasarkan Tabel 4.6 nilai Fhitung sebesar 49,465 dengan signifikansi 0,000 $<0,05$ (yang ditetapkan) maka dapat diartikan bahwa secara bersama- sama terdapat pengaruh yang signifikansi antara variabel PER, EPS, DYR, DPR, BVS, PBV terhadap harga saham.

\section{Uji t(Parsial)}

Tabel 4.7

Hasil Uji t (Parsial)

\begin{tabular}{|l|r|r|r|r|r|}
\hline Model & \multicolumn{2}{|c|}{ Unstandardized } & Standardized & \multirow{2}{*}{ T } & Sig \\
\cline { 2 - 5 } & \multicolumn{1}{|c|}{ B } & Std. Error & Beta & & . \\
\hline - Constant & 5,278 &, 781 & & 6,761 &, 000 \\
PER &, 388 &, 114 &, 327 & 3,419 &, 002 \\
EPS &, 105 &, 051 &, 178 & 2,048 &, 049 \\
DYR &,- 335 &, 123 &,- 283 & $-2,712$ &, 011 \\
DPR &, 055 &, 058 &, 084 &, 954 &, 347 \\
BVS &, 189 &, 076 &, 194 & 2,495 &, 018 \\
PBV &, 383 &, 095 &, 464 & 4,049 &, 000 \\
\hline
\end{tabular}

Sumber: Output SPSS versi 20, 2015

Besarnya angka ttabel dengan ketentuan $\alpha=0,05$ dan $\mathrm{dk}=(\mathrm{n}-2)$ atau $(40-2)=$ 38 sehingga diperoleh nilai ttabel sebesar 1.68595. Berdasarkan Tabel 4.7, maka dapat diketahui pengaruh masing-masing variabel sebagai berikut:

\section{Variabel PER terhadap harga saham}

Dari tabel coefficients diperoleh nilai thitung $=3,419$ yang artinya thitung > 
I-Finance Vol. 3. No. 2. Desember 2017

Pengaruh Price Earning Ratio ....Lidia Desiana

ttabel $(3,419>1.68595)$ dengan signifikansi $0,002<0,05$ artinyasecara parsial terdapat pengaruh antara PER terhadap harga saham.

\section{Variabel EPS terhadap hargasaham}

Dari tabel coefficients diperoleh nilai thitung $=2,048$ yang artinya thitung $>$ ttabel $(2,048>1.68595)$ dengan signifikansi $0,049<0,05$. Sehinggadapat disimpulkan bahwa secara parsial EPS berpengaruh terhadap harga saham.

\section{Variabel DYR terhadap hargasaham}

Dari tabel coefficients diperoleh nilai thitung $=-2,712$ yang artinya thitung < ttabel $(-2,712<1.68595)$ dengan signifikansi $0,011<0,05$. Sehingga dapat disimpulkan bahwa secara parsial DYR tidak berpengaruh terhadap harga saham.

\section{Variabel DPR terhadap hargasaham}

Dari tabel coefficients diperoleh nilai thitung $=0,954$ yang artinya thitung < ttabel $(0,954<1.68595)$ dengan signifikansi $0,347>0,05$. Sehingga dapat disimpulkan bahwa secara parsial DPR tidak berpengaruh terhadap harga saham.

\section{Variabel BVS terhadap hargasaham}

Dari tabel coefficients diperoleh nilai thitung $=2,495$ yang artinya thitung > ttabel $(2,495>1.68595$ dengan signifikansi $0,018<0,05$. Sehingga dapat disimpulkan bahwa secara parsial terdapat pengaruh antara BVS terhadap harga saham.

\section{Variabel PBV terhadap harga saham}

Dari tabel coefficients diperoleh nilai thitung $=4,049$ yang artinya thitung $>$ ttabel $(4,049>1.68595)$ dengan signifikansi $0,000<0,05$. Sehinggadapat disimpulkan bahwa secara parsial terdapat pengaruh antara PBV terhadap harga saham.

\section{B. Pembahasan}

Berdasarkan hasil penelitian, diketahui bahwa PER berpengaruh terhadap harga saham, artinya bahwa setiap kenaikan variabel PER dapat menaikan harga saham dan mampu mempengaruhi harga saham yang akan datang. Price Earning Ratio (PER) merupakan rasio yang membandingkan antara harga pasar per lembar saham (market price share) dengan penghasilan per lembar saham (earning per share). Rasio ini sering digunakan untuk membandingkan peluang investasi. ${ }^{7}$ Suatu perusahaan yang memiliki PER yang tinggi, berarti perusahaan tersebut mempunyai tingkat pertumbuhan yang tinggi hal ini menunjukan bahwa pasar mengharapkan pertumbuhan laba dimasa mendatang, sebaliknya perusahaan dengan PER rendah akan mempunyai tingkat pertumbuhan yang rendah, semakin rendah PER suatu saham maka semakin baik atau murah harga untuk diinvestasikan. ${ }^{85} \mathrm{Hal}$ ini sesuai dengan penelitian Dady Suhadi (2009) dan Sri Zuliarni (2012) yang menyimpulkan bahwa PER berpengaruh terhadap harga saham.

Hasil penelitian menujukkan bahwa EPS tidak berpengaruh terhadap harga

\footnotetext{
${ }^{7}$ Budi Rahardjo, Laporan Keuangan Perusahaan, (Yogyakarta : UGM Press, 2009), hlm.151
} 
saham.EPS menunjukkan kemampuan perusahaan dalam menghasilkan keuntungan bersih dalam setiap lembar sahamnya.Biasanya penghasilan per lembar saham biasa mempengaruhi harga saham di bursaefek. ${ }^{8}$ Artinya semakin besar EPS maka tidak dapat digunakan untuk memprediksi pergerakan harga suatu saham. Semakin tinggi nilai EPS berarti tidak akan meningkatkan harga saham perusahaan. semakin besar EPS akan semakin menurunkan harga saham. Hasil penelitian ini sesuai dengan penelitian Vernande Nirohito (2009) bahwa EPS secara parsial tidak berpengaruh terhadap hargasaham.

Hasil penelitian ini menjelaskan DYR tidak berpengaruh terhadap harga saham. Hal ini menunjukkan Semakin tinggi atau rendahnya nilai dividend yield tidak akan mempengaruh harga suatu saham. perusahaan dengan prospek yang tinggi akan mempunyai harga pasar saham yang tinggi, yang berarti pembaginya tinggi, maka dividend yield untuk perusahaan macam ini akan cenderung lebih rendah. ${ }^{9}$ Dividend yield pada dasarnya adalah persentase deviden yang diterima dibandingkan dengan harga beli suatu saham.Harga saham perusahaan terus berubah dan tidak sejalan dengan besarnya nilai dividend yield perusahaan.Hal ini menyebabkan calon investor mengambil keputusan untuk berinvestasi tidak dipengaruhi oleh faktor pembayaran deviden oleh perusahaan.

Hasil penelitian ini sesuai dengan penelitian yang dilakukan Rani Ramdhani (2012) bahwa DYR tidak berpengaruh terhadap hargasaham.Hasil penelitian menunjukkan bahwa DPR tidak berpengaruh terhadap harga saham, Bahwa deviden yang dibayarkan oleh emiten kepada parapemegang saham tidak menyebabkan naiknya nilai perusahaan. Rasio ini adalah perbandingan antara dividen yang dibagikan dengan laba bersih yang diperoleh perusahaan, biasanya disajikan dalam bentuk presentase. ${ }^{10}$ Jadi DPR tidak dapat dijadikan sebagai faktor penting bagi investor dalam membuat keputusan investasi.Hasil penelitian ini sesuai dengan penelitian yang dilakukan oleh Sri Zuliarni (2012) dan Gede Priana Dwipratama (2007).

Hasil penelitian menunjukkan bahwa BVS berpengaruh terhadap harga saham, artinya bahwa para pemegang saham perlu memperhitungkan besar kecilnya nilai $\mathrm{BV}$, karena besar kecilnya nilai BV terdapat mempengaruhi perubahan harga saham di pasar modal. Nilai buku (book value) per lembar saham menunjukkan aktiva bersih (net assets) yang dimiliki oleh pemegang saham dengan memiliki satu lembar saham. Karena aktiva bersih adalah sama dengan total ekuitas pemegang saham, maka nilai buku per lembar saham adalah total ekuitas dibagi dengan jumlah saham yang beredar. ${ }^{11}$ Hasil penelitian ini sesuai dengan penelitian yang dilakukan oleh Vernande Nirohito(2009).Hasil penelitian menunjukkan bahwa PBV berpengaruh terhadap harga saham. Rasio ini menggambarkan seberapa besar pasar menghargai nilai buku saham suatu perusahaan. Semakin tinggi rasio ini akan memberikan gambaran bahwa semakin tingginya harga saham perusahaan menunjukkan semakin baiknya kinerja perusahaan. Semakintinggiperusahaan dinilai oleh

\footnotetext{
${ }^{8}$ Budi Rahardjo, Laporan Keuangan Perusahaan, (Yogyakarta : UGM Press, 2009),hlm.150

${ }^{9}$ Hanafi, Mamduh M, Manajemen Keuangan, hlm. 43

10 J.P Sitanggang, Manajemen Keuangan Perusahaan, (Jakarta: Mitra Wacana Media, 2012), hlm.6

${ }^{11}$ Jogiyanto Hartono, Analisis dan Desain Sistem Informasi : Pendekatan Terstruktur Teori dan Praktek Aplikasi Bisnis, hlm. 82
} 
I-Finance Vol. 3. No. 2. Desember 2017

Pengaruh Price Earning Ratio ....Lidia Desiana

para pemodal relatif dibandingkan dengan dana yang telah ditanamkan di perusahaan. Jika pada analisis book value, investor hanya mengetahui kapasitas per lembar dari nilai saham, pada rasio Price to Book Value (PBV) investor dapat mengetahui langsung sudah berapa kali market value suatu saham dihargai dari book value-nya. ${ }^{12}$ Penilaian perusahaan oleh investor akan sangat mempengaruhi keputusan investasi, karena investor akan berinvestasi diperusahaan yang memiliki kinerja baik. Rasio ini menggambarkan kepercayaan pasar akan prospek keuangan perusahaan tersebut. Hal ini berarti investor mempunyai kepercayaan yang tinggi pada perusahaan dengan melakukan pembelian saham.Hasil penelitian ini sesuai dengan penelitian yang dilakukan Sasongko Tri Utomo (2013) dan Dady Suhadi(2009).

\section{KESIMPULAN DANSARAN}

\section{Kesimpulan}

Berdasarkan hasil analisis data dan pembahasan yang sudah duraikan, dapat ditarik kesimpulan sebagaiberikut:

1. Variabel Price Earning Ratio (PER), Earning Per Share (EPS), Book Value Per Share (BVS), Price Book Value (PBV) secara parsial berpengaruh terhadap harga saham.Variabel Devidend Payout Ratio (DPR) dan Devidend Yield Ratio (DYR), secara parsial tidak berpengaruh terhadap harga saham. Secara simultan Variabel Price Earning Ratio (PER), Earning Per Share (EPS), Devidend Yield Ratio (DYR), Devidend Payout Ratio (DPR), Book Value Per Share (BVS), Price Book Value (PBV) berpengaruh terhadap hargasaham.

2. Variabel Price Book Value (PBV) adalah variabel yang paling dominan berpengaruh terhadap hargasaham.

\section{Saran}

Berdasarkan kesimpulan penelitian ini, dapat diberikan saran bahwa:

1. Bagi para investor hendaknya dapat mempertimbangkan kinerja perusahaan sebelum memutuskan pilihan dalam berinvestasi terutama pada perusahaan sub sektor food and beverage yang terdaftar di Jakarta Islamic indeks, dengan memperhatikan rasio-rasio keuangan perusahaan baik berupa variabel dalam penelitian ini maupun yang tidak termasuk dalam penelitian.

2. Bagi penelitian pendatang, perlu manambahkan perusahaan sebagai objek penelitian dan rasio keuangan lain sebagai variabel independen karena ada rasio keuangan yang tidak dimasukkan dalam penelitian ini berpengaruh terhadap hargasaham

\section{DAFTAR PUSTAKA}

Adi, Angantyo dkk. 2012. Pengaruh ROE, DER, EPS, Dan BVS Terhadap Harga Saham Studi pada Perusahaan Consumer Goods Industry yang Terdaftar di BEI Periode Tahun 2008 - 2011.Jurnal.

Adiguna, Kadek Anom. 2012. Analisis Pengaruh EPS, PER, dan Dividend Yield Serta Aliran Dana Asing Terhadap Perubahan Harga Saham Blue Chip dan Harga Saham Lini Kedua Di Bursa Efek Indonesia Tahun 2009 -

\footnotetext{
${ }^{12}$ Tryfino, Cara CerdasBerinvestasi Saham, (Jakarta: Transmedia Pustaka, 2009), hlm. 9
} 
I-Finance Vol. 3. No. 2. Desember 2017

Pengaruh Price Earning Ratio ....Lidia Desiana

2011.Skripsi (tidak diterbitkan).

Amanda, Astrid dkk. 2012. Pengaruh Debt To Equity Ratio, Return On Equity, Earning Per Share, dan Price Earning Ratio Terhadap Harga Saham (Studi pada Perusahaan Food and Beverages yang Terdaftar di BEI Tahun 2008-2011. Jurnal.

Hamid, Abdul. 2009. Pasar Modal Syariah. Jakarta: Lembaga Penelitian UIN Jakarta.

Haron, Sudin dan Wan Nursofiza. 2008. "Creating a Dynamic Islamic Capital Market: The Essential Role of Innovation." Dalam Islamic Capital Market: Products, Regulation \&Development, Salman Syed, ed. Jeddah: Islamic Development Bank Islamic Research and Training Institute.

Ikatan Akuntan Indonesia. 2012. Standar Akuntansi keuangan per 1 Juni 2012, Jakarta : Salemba Empat.

Kusuma, Denies Priatinah Prabandaru Adhe. 2012. Pengaruh Return On Invvestment (ROI), Earning Per Share (EPS), dan Dividen Per Share (DPS) Terhadap Harga Saham Perusahaan Pertambangan yang Terdaftar Di Bursa Efek Indonesia (BEI) Periode 2008-2010.Jurnal

Muhammad, Gunawan Yasni. 2012. "Kami Terus Menyempurnakan Kriteria Efek Syariah.'Laporan Utama, Majalah Sharing, Edisi Maret.

Munawir. 2010. Analisis Laporan Keuangan. Edisi 4, Liberty, Yogyakarta.

Rahardjo, Budi. 2009. Laporan Keuangan Perusahaan. Yogyakarta : UGM Press.

Ramdhani, Rani. 2012. Pengaruh Devidend Yield dan Earning VolatilityTerhadap Votalistas Harga Saham Di Bursa Efek Jakarta. Jurnal.

Sanusi, Anwar. 2011, Metode Penelitian Bisnis, Salemba Empat, Jakarta.

Sjahrial, Dermawan. 2009. Manajemen Keuangan (3th ed). Jakarta: Mitra Wacana Media.

Siregar, Syofian. 2013. Statistik Parametik untuk Penelitian Kuantitatif Dilengkapi dengan Perhitungan Manual dan Aplikasi SPSS Versi 17. Jakarta: BumiAksara.

Sitanggang, J.P. 2012. Manajemen Keuangan Perusahaan. Jakarta: Mitra Wacana. Sugiyono. 2012. Memahami Penelitian Kualitatif. Bandung: Alfabeta.

Suhadi, Dady. 2009. Pengaruh Rasio Aktivitas, Rasio Profitabilitas, Rasio Laverage, dan Rasio Penilaian Terhadap Harga Saham Perusahaan Food and Beverage. Jurnal.

Suharso, Yudi. 2014. OJK Paparkan Perkembangan Terbaru Pasar Modal Syariah. http://mysharing.co/ojk-paparkan-perkembangan-terbaru-pasar- modalsyariah/. (diakses, 20 November 2015).

Sunyoto, Danang. 2011. Analisis Regresi dan Uji Hipotesis. Yogyakarta, CAPS. Supangat.

Tandelilin, Eduardus. 2010. Portofolio dan Investasi: Teori dan Aplikasi.Yogyakarta: Kanisius.

Tryfino. 2009. Cara Cerdas Berinvestasi Saham, Edisi Pertama, Jakarta: Transmedia Pustaka.

Utomo, Sasongko Tri. 2013. Analisis Pengaruh Rasio Nilai Aktivitas dan Nilai Pasar Terhadap Perubahan Harga Saham.Skripsi (tidak diterbitkan).

Yuliana, Indah. 2010. Investasi Produk Keuangan Syariah- Malang: UIN- MALIKI PRESS, Buku Panduan Harga Saham Bursa Efek Indonesia, Jakarta: 
I-Finance Vol. 3. No. 2. Desember 2017

Pengaruh Price Earning Ratio ....Lidia Desiana

Indoesian Stock Exchange.

Zuliarni, Sri 2012. Pengaruh Kinerja Keuangan Terhadap Harga Saham Pada Perusahaan Mining and Mining Service Di Bursa Efek Indonesia (BEI).Jurnal.

www.analisaforex.com

www.bapepam.go.id

www.idx.co.id

WwW.indofoodcbp.com

www.indofood.com

www.seputarforex.com 